\title{
DOE/MT/92017--05
}

\section{Simultaneous $\mathrm{SO}_{2} / \mathrm{NO}_{\mathrm{x}}$ Abatement Using Zeolite-Supported Copper}

\author{
Progress Report \\ October 1, 1995 - September 30, 1996
}

\author{
By: \\ Mark B. Mitchell \\ Mark G. White
}

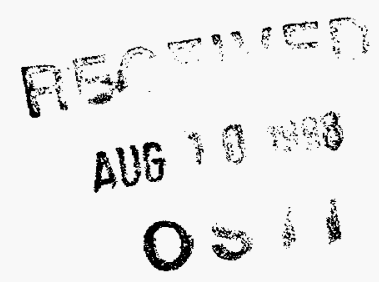

Work Performed Under Contract No.: DE-FG22-92MT92017

For

U.S. Department of Energy

Office of Fossil Energy

Federal Energy Technology Center

P.O. Box 880

Morgantown, West Virginia 26507-0880

By

Clark Atlanta University

223 James P. Brawley Drive

Atlanta, Georgia 30314

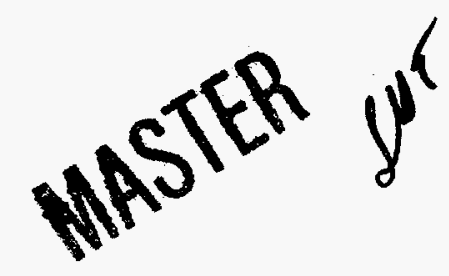




\section{Disclaimer}

This report was prepared as an account of work sponsored by an agency of the United States Government. Neither the United State Government nor any agency thereof, nor any of their employees, makes any warranty, express or implied, or assumes any legal liabilit or responsibility for the accuracy, completeness, or usefulness of an information, apparatus, product, or process disclosed, or represents that its use would not infringe privately owned rights. Reference herein to any specific commercial product, process, or service by trade name, trademark, manufacturer, or otherwise does not necessarily constitute or imply its endorsement, recommendation, or favoring by the United States Government or any agency thereof. The views and opinions of authors expressed herein do not necessarily state or reflec those of the United States Government or any agency thereof. 


\section{ABSTRACT}

The bulk of the results from this project, besides being found in the research reports, are in the form of two theses presented for advanced degrees by two different students at two different institutions. Francis E. Porbeni is a Master's Degree student in Chemistry at Clark Atlanta University and has prepared his Master's Thesis entitled Simultaneous $\mathrm{SO}_{2}$ Oxidation and NO Decomposition over Copper Oxide on $\gamma$-Alumina Catalysts: An Infrared Diffuse Reflectance Study. Sumit Rao, a Ph.D. student in Chemical Engineering at the Georgia Institute of Technology has defended his thesis entitled Role of Copper Ensemble Size in Silica and Zeolite Supported Catalysts for Nitric Oxide Decomposition. These two documents, which will be forwarded when final copies are available, provide the details of the bulk of the research accomplished over the duration of this project. These two documents are summarized, and other results from the project are given, below.

\section{SUMMARY OF RESEARCH ACCOMPLISHMENTS}

\section{Research Presented in the Thesis of Francis E. Porbeni}

\section{Preparation of Novel CuO/ $\gamma$-Alumina Catalysts using Non-Aqueous Impregnation.}

Non-aqueous impregnation using acetonitrile as the solvent and copper acetylacetonate as the copper precursor yield intact complexes on the support, apparently well-dispersed over the surface. The adsorption isotherm for these compexes is linear over the measured concentration range, and elemental analysis and infrared spectroscopy both indicate that the complex is probably intact on the surface before calcination. After calcination, the copper atoms act chemically as copper aluminate, as observed by both $\mathrm{SO}_{2}$ and $\mathrm{NO}$ chemisorption.

\section{$\mathrm{SO}_{2}$ Adsorption and Reaction on $\mathrm{CuO} / \gamma$-Alumina.}

$\mathrm{SO}_{2}$ adsorbs on the $\mathrm{CuO} / \gamma$-alumina sorbent at both copper and aluminum sites. Adsorption at the aluminum sites leads to the formation of both aluminum sulfite and sulfate species, even in the absence of added oxygen. The formation of aluminum sulfate may be due to oxygen spillover effects. The adsorption efficiency increases with temperature up to at least 300 ${ }^{\circ} \mathrm{C}$. This is in contrast to the situation on pure aluminum oxide or sodium-doped alumina for which $150^{\circ} \mathrm{C}$ yielded the highest adsorption efficiency.

Upon oxidation, the adsorbed $\mathrm{SO}_{2}$ is converted to copper sulfate, regardless of its initial oxidation state or associated cation. The exception to this is found at the lowest copper loadings, where adsorbed $\mathrm{SO}_{2}$ may not be able to "reach" surface copper species.

\section{NO Adsorption on $\mathrm{CuO} / \gamma$-Alumina and on Sulfated $\mathrm{CuO} / \gamma$-Alumina.}

$\mathrm{NO}$ adsorbs on the $\mathrm{CuO} / \gamma$-alumina surface to give rise to three different species. One species corresponds to the complex formed between the surface $\mathrm{Cu}$ species, as $\mathrm{Cu}^{2+}$, and neutral NO. This species gives rise to an absorption band virtually identical to that observed by others for NO adsorbed on copper aluminate. Additionally, two other bands are formed. A very weak band at approximately $1700 \mathrm{~cm}^{-1}$ has been assigned as being due to the formation of $\mathrm{Cu}^{+} / \mathrm{NO}^{-}$species. 


\section{DISCLAIMER}

Portions of this document may be illegible in electronic image products. Images are produced from the best available original document. 
A medium feature at $1640-1627 \mathrm{~cm}^{-1}$ is assigned as corresponding to the formation of $\mathrm{Cu}^{+}-\mathrm{ONO}$. This latter feature is by far the most intense feature in the spectrum, and is indicative of the participation of the surface $\mathrm{Cu}$ species in a redox reaction, leading to the formation of $\mathrm{NO}_{2}$ from the adsorbed NO. When the surface is sulfated, i.e. by exposure to $\mathrm{SO}_{2}$ and $\mathrm{O}_{2}$ at high temperature, the adsorption chemistry of NO is changed dramatically. NO again adsorbs at the $\mathrm{Cu}^{2+}$ surface sites, but the formation of the $\mathrm{Cu}^{+}$species is almost eliminated. Only a small contribution from the $\mathrm{Cu}^{+}-\mathrm{ONO}^{-}$species is observed in the infrared spectrum, and the band due to the $\mathrm{Cu}^{+} / \mathrm{NO}^{-}$species is not evident at all. This indicates that sulfation of the surface, locks the $\mathrm{Cu}^{2+}$ species into the +2 oxidation state, and precludes participation of copper species in surface redox chemistry, which is critical if the NO reduction reaction is to occur.

\section{Research Presented in the Thesis of Sumit N. Rao}

\section{The Role of the Formation of $\mathrm{Cu}^{2+}-\mathrm{OH}^{-}$Complexes.}

The state of the art catalyst for NO reduction involves the batch impregnation of ZSM-5 zeolite with copper acetate in aqueous solution. Much discussion has been carried out in the literature regarding the active form of copper in the zeolite, whether the active species is $\mathrm{Cu}^{2+}$ or $\mathrm{Cu}^{+}$, or if the coordination number of the copper is the important parameter, or whether the number of copper atoms in close proximity is important for NO reduction activity. The copper is ion-exchanged into the zeolite, and as such, if it is to reside as $\mathrm{Cu}^{2+}$ in the zeolite, it must find a site where two aluminum ions are close together, so that the local charge in that region of the zeolite framework can compensate its +2 charge.

Some speculation has involved the formation of a $\mathrm{Cu}^{2+}-\mathrm{OH}^{-}$species, with overall charge +1 , which would not need to find two aluminum sites close together, but which could ionexchange at any single aluminum site to form a neutral complex. Two different experiments were carried out to evaluate the effects of reducing the $\mathrm{OH}^{-}$solution concentration during impregnation. The first experiment used added acetic acid to shift the water dissociation equilibrium back towards $\mathrm{H}_{2} \mathrm{O}$ and away from the formation of $\mathrm{OH}^{-}$in solution. Catalysts prepared using an impregnation solution containing added acetic acid showed less activity overall and less activity per copper atom than the state of the art catalyst. The second experimentinvolved the use of acetonitrile as the solvent for the impregnation of ZSM-5 with copper acetate. The catalyst produced using this solution was almost completely inactive.

\section{The Role of $\mathrm{Cu}$ Atoms Next to Two Aluminum Atoms.}

As mentioned above, speculation regarding the nature of the active copper species for NO reduction has involved whether the copper is sited next to one or two aluminum atoms in the zeolite framework. Experiments were carried out using non-aqueous impregnation with copper ethylenediamine as a precursor for $\mathrm{Cu}^{2+}$. This complex in acetonitrile solution does not dissociate and certainly there are no $\mathrm{Cu}^{2+}-\mathrm{OH}^{-}$species formed, so that the copper atom, when it does adsorb onto the surface, must find two aluminum atoms in the zeolite framework to compensate its +2 charge. Copper ethylenediamine is a stable source for $\mathrm{Cu}^{2+}$ and there is virtually no possibility that the copper would adsorb as $\mathrm{Cu}^{+}$. Thus, catalysts prepared in this way are a known source of copper in the neighborhood of two framework aluminum atoms. These catalysts yield activity per 
Rao, S.; Waddell, E.; Mitchell, M. B.; White, M. G. "Selective Sulfur Dioxide Adsorbents Prepared from Designed Dispersion of Goup IA \& IIA Metal Oxides on Alumina," AIChE National Meeting, St. Louis, MO, November 8 - 12, 1993. 